\title{
The Art of Digital Scent - People, Space and Time
}

\author{
Mei-Kei Lai \\ Design Programme, School of Arts, Macao Polytechnic \\ Institute, \\ Macao \\ mklai@ipm.edu.mo; meikei.lai@gmail.com \\ $---$
}

\section{ABSTRACT}

The sense of smell is closely related with people across time and space. The aesthetic, affective and evocative aspects of smell are widely portrayed in art practices. Olfactory art has its unique expression that other modalities hardly have. Yet this aesthetic medium seems to be underestimated when it comes to the digital age. Current digital olfaction researches mainly focus on meeting tasks and solving problems. The aesthetic experience and the meaning behind are seldom discussed. This paper proposes a potential area where the people from digital art and digital olfaction can contribute together. This paper firstly gives an overview about the affective and evocative impacts of scent on people across time and space, reviewing how scent is treated as the aesthetic medium in the art form, then examining current usages of olfactory display, and lastly discussing the opportunities lying ahead. It provides the way to appreciate the world aesthetically through this affective and evocative medium.

\section{KEYWORDS}

Olfactory Art; Digital Olfaction; Olfactory Interface; Digital Art; Interactive Olfactory Art; Experience Design; Aesthetic; Scent; Odour.

\section{ARTICLE INFO}

Received: 04 March 2018

Accepted: 31 July 2018

Published: 01 November 2018

https://dx.doi.org/10.7559/citarj.v10i1.501

\section{1 | INTRODUCTION}

Scent is craftwork that requires beauty and intelligence (Turin, 2007). Scent is depicted aesthetically throughout literature from East to West. Japanese novelist Murasaki Shikibu told us how the scent of incense brought the beauty of ladies to the prince in The Tale of Genji (Gatten, 1977). Brazilian novelist Paulo Coelho (2002) told us how the scent of wind brought the kisses of veiled women to Santiago even in the threat of the desert in The Alchemist. French novelist Marcel Proust (1982) showed us how a long-forgotten childhood memory was brought to the narrator in a vivid way through the scent of madeleine dipped into a cup of tea in his famous novel Remembrance of Things Past. German writer Patrick Süskind (2001) told us a story how the perfumer was obsessed with the scent of young women in Perfume: The Story of a Murderer. In literature, scent not only portrays the beauty and identity of the characters, but also evokes the imagination and long-lost memory of the characters across time and space.

The aesthetic impact of scent can be found in cultural and religious practices as well. In the Japanese Kodo incense ceremony, the scent of incense is treated as an art of refinement (Morita, 2006). It is known as the art of appreciating incense with body and soul. The compounding of incense requires training and skill like poetry or calligraphy. In Catholic liturgy, the scent of incense is treated as symbolic of sanctification and purification. The priests swing the thurible filled with the scent of incense to represent prayers to Heaven at Mass. The affective and evocative aspect of scent enriches 
the aesthetic experience in a way that other sensations hardly provide.

When scent is put into the hands of artists, it is treated as an art form in an aesthetic way. Olfactory art critic Jim Drobnick (1998) categorized olfactory artworks into two main approaches. One approach is to emphasize scent as a fundamental element with its own value. Scent is shown as art on its own merits. Another approach is to use scent as a symbolic way to associate with individual identity, lived experience and cultural sensibility, etc. These two approaches can be found respectively in the exhibition titled The Art of Scent 1889-2012 curated by Chandler Burr and the exhibition titled The Scent of Art curated by Belle Haleine (Osman, 2015). Chandler Burr exhibited scent for its own sake by taking away all the bottles and the packing usually seen in commercial perfumes. They displayed the scent with its name and creator like a piece of art in a museum. Each scent was given a background story. It let the visitors appreciate the scent itself with its top, middle and base notes. Burr believed that scent should be treated as legitimate as conventional art like painting and music (Orlin, 2012). Belle Haleine approached from another perspective by presenting the odours with its own artistic expression. The exhibited odours included bodily odours like urine, skin, and pheromones; also, natural scents like lilies, garlic and spices. The expressions were varied including installations, videos, sculptures, drawings, photographs, etc ("Belle Haleine," 2015).

Artists have been exploring various ways to use scents in a symbolic way in artwork. For example, artist Sissel Tolaas (2006) associated odours with the emotion of fear. She let participants experience her installation The Smell of Fear by providing the odour captured from the sweat of twenty men who suffered from phobia. Artist Peter De Cupere treated the odours as symbolic of a dead body, gun powder, and blood in his artwork The Smell of a Stranger. It contrasted the beauty of the displayed Cuban flowers with the odours association with sex tourism, air pollution, and death. The artist used olfactory artwork to criticize the probable damage to Cuba's environment caused by the US-Cuban trade (Brooks, 2015). Brazilian artist Ernesto Neto put various spices into transparent fabric making an olfactory sculpture hanging from the ceiling in Centre Pompidou ("We stopped just here," 2002).
When it comes to the digital age, the characteristics of odour bring certain challenges in capturing and generating scent in computer systems. The field of digital olfaction has been exploring various ways to tackle these issues, especially in olfactory display. Applications can be found in areas such as enhancing the realism of virtual environments (Ischer et al., 2014), converting information (Seah et al., 2014), stimulating gustatory perception (Narumi et al., 2010), etc. However, the studies mainly focus on how accurately the systems deliver the scents and how well people perceive the scents from the olfactory display. The aesthetic aspect of digital olfaction is seldom mentioned. This seems to be an area where people from digital art and digital olfaction can work together to advance this field. This paper proposes to bring these two areas together by firstly giving an overview about the affective and evocative impacts of scent on people across time and space, reviewing how scent is treated as an aesthetic medium in art form, then examining current usage of digital olfaction, especially olfactory display in different aspects, and lastly discussing the opportunities of bringing the aesthetics of scent into digital olfaction.

\section{2 | THE IMPACT OF SMELL}

\subsection{PEOPLE}

The sense of smell has affective and evocative impact on people across time and space. The smell of their mother brings joy to new-borns (Sullivan \& Toubas, 1998). The smell of sweat on clothing brings the sense of presence to a distant couple (McBurney, Streeter, \& Euler, 2012). The smell of vanilla increases sales in department stores (Spangenberg, Sprott, Grohmann, \& Tracy, 2006). The smell of chocolate makes bookstore customers more likely to buy cookbooks and romantic literature (Doucé, Poels, Janssens, \& De Backer, 2013). The perceptual and cognitive responses to odours are based on associative learning from previous experience. It makes olfactory perception and the associated memories subjective among individuals (Herz, 2012). When encountering a new odour, the brain associates the odour with the encountered episode together. If the odour is initially perceived in a pleasant context, this odour would bring a pleasant emotion to the subject in the future. It is determined by the situational context in the first encountered experience (Engen, 1991). 
Due to a large gene family in olfactory receptors, humans can discern 10,000 different odours (Buck \& Axel, 1991). However, it is not always easy to identify and describe. Perfumers have their terminology to classify odours using the fragrance wheel. Yet this terminology is not widely used among the general public (Teixeira, Rodríguez, \& Rodrigues, 2010). People tend to describe odours in association with objects, places, and previous experiences-for example, the smell of rose, the smell of hospital, the smell of summer vacation, etc. The description includes public and private meaning. While "the smell of rotten eggs" conveys shared experience and similar message among the general public, "the smell of my childhood playground" conveys a personal experience and its private meaning (Almagor, 1990). Smell also marks the culture and ethnicity in a society (Classen, Howes, \& Synnott, 1994). In the eighteenth and nineteenth centuries, smells were the indicator of class and gender in French society. Pleasant smells were associated with good health and cleanliness while unpleasant ones were related to diseases and decay. People used fragrances to mask the stink of odours in the old days (Corbin, 1986) whereas people nowadays wear fragrances to represent their personality and mood.

\subsection{SPACE}

Smell defines the territory of space. People might be aware of the existence of a fish market or bakery nearby before they reach the place. The Hard Rock Hotel in Orlando used artificial waffle scents as the sensory cue to lead the people downstairs to an icecream store which usually was not noticed by the customers (Lewis, 2013). The smell of space implies its identity as well. Some luxury hotels developed signature scents to show their identities. It helped to connect their customers with the brands and to promote the liking of the service (Denizci Guillet, Kozak, \& Kucukusta, 2017). The signature scent serves as the memory cues for the customers to recall their experience in the hotels.

Smell also affects how people perceive a place in a subconscious way. For example, the scent of lavender made people perceive a room with pleasantness and warmth. The relevance of congruence and the coherence between scent and physical environment can enhance the user experience in a space (Vilaplana \& Yamanaka, 2014). Shibuya Hikarie, a shopping mall located in
Tokyo, provided different scents in the female toilets on different floors to give the customers a change of mood. They called their toilets as "Switch Rooms" ("Cities, firms clean up," 2015). Smell also tells the stories of cities. Rachel Huang launched a free tour in Taiwan called Smells of Taipei which led the locals and the tourists to experience the old streets through their smells. Huang told stories of the city along the tour when the participants encountered different smells on the streets (Wei, 2015). Henshaw et al. (2016) proposed the use of scents in city marketing. It brings a new way for the sensory design of environments for urban identity.

\subsection{TIME}

Helen Keller once described that, "Smell is a potent wizard that transports you across thousands of miles and all the years you have lived." Larsson et al. (2014) indicated that the memories evoked by odours were older than those evoked by other sensory modalities. Those memories were mainly associated with the first ten years of life and triggered the emotion that affected human behaviour unconsciously. Neurologist Alan R. Hirsch (2006) found that the nostalgic memories evoked by odour were varied depending on the olfactory experiences of the generations. He once interviewed one thousand shoppers randomly in Chicago about their odour-evoked memories. He found that those who were born around the 1930s related nostalgic memories to natural odours like flowers, grass and sea; whereas those who were born around the 1970s referred to artificial odours like baby powder, mother's perfume and suntan oil. Sociologists Waskul et al. (2009) found that people described the odour-evoked memories vividly within a precise context. One lady aged 49 described vividly how a particular smell brought her the feeling of being a little girl giving her father a welcome home hug. Another participant wrote in journals describing that, "The smell of baking makes me think of a cozy house on a cold night with my family sitting around with a treat after dinner." This evocative retrieving experience elicited by olfaction is known as "Proust Phenomenon". Sugiyama et al. (2015) took this phenomenon into product evaluation. They found that a lotion scented with fragrance which evoked autobiographical relevant memories was perceived more appealing compared with another one scented with an equivalently pleasant fragrance yet without any autobiographical relevant memories. 
Scents not only bring us long-lost memories, but also tell us the passing of time. In an ancient time, people used incense clocks to measure the time through the combustion rate. They noticed the passing of hours through smelling the change of scents from different burning incense (Bedini, 1994). This idea was adopted into the smell-based alarm clock in the digital age. Sensorwake, a Kickstarter project launched in 2015, let users setup different scents in the alarm. It provided the scent of coffee, croissants, and ocean to wake up the users in the morning ("Sensorwake Wake Up Happy," 2015).

\section{3 | THE ART OF SMELL}

\subsection{SMELL AS ART}

In the history of olfactory art, artists took smell as the medium to challenge the visually dominated world. Marcel Duchamp's artwork shown in the exhibition Exposition Internationale du Surréalisme in 1938 was considered as the earliest olfactory artwork. Duchamp presented the aroma of roasting coffee with his installation to argue that art was not "retinal" only (Osman, 2013). Later Fluxus artist Takako Saito made her artwork Spice Chess by filling the chess pieces with different spices but in identical shaped bottles. The players had to sniff to identify the spice before moving the chess pieces. Saito took the scents in the form of chess pieces to imply the status and movement of individuals in society. She challenged the boundary of art through experimental olfactory artwork ("Takako Saito," n.d.). In 2008, Tom Russotti and Larry Miller echoed Saito's artwork by showing their Smell Chess in the exhibition Flux-Olympiad 2008 in Tate Modern. The vagueness of the scent became both the challenge and the enjoyment of the experience for the visitors (Finbow, 2015). American artist Walter De Maria's The New York Earth Room spread 280,000 pounds of soil over 3,600 square feet with 22 inches depth on an entire floor in a Soho loft in New York City. The scent of moist musky earth gave the visitors an imagery of nature hardly experienced in a concrete building ("Walter De Maria," n.d.).

Other artists considered the change of odour during time as part of the art itself. Belgian artist Jan Fabre did a series of olfactory artworks by taking naturally changing smell, usually the stench, as conceptual art itself. The smell produced from his artworks included the smell of spoiling onion and the smell of rotting ham ("Installation on the nose," 2008). British artist Damien Hirst (1990) blended the smell of decaying cow's head with flies in his artwork $A$ Thousand Years. In these artworks, the odours represented the passing of time and the decay of objects. In 2012, a non-profit organisation called The Institute for Art and Olfaction was founded in Los Angeles. It aims to initiate and to support arts projects that utilize the medium of scent. They hold the Art and Olfaction Awards annually not only for perfumes, but also for olfactory art projects. They provide a platform bringing perfumers, artists, and scientists together to explore the boundaries of olfactory aesthetics ("The Institute for Art and Olfaction," n.d.).

\subsection{SMELL AS AESTHETIC MEDIUM}

Smell is treated as an aesthetic medium to augment the conventional visual art experience (Shiner \& Kriskovets, 2007). In 2015, the Tate Sensorium (Tate, n.d.) exhibition, held in Tate Britain, aimed to bring visitors a new way to appreciate the Tate collection with multi-sensation. Based on selected British Art paintings, London studio Flying Object provided different olfactory experiences along with the artworks. For example, they used the smell of grass and soil to exhibit along with Francis Bacon's Figure in a Landscape 1945, the smell of diesel and tobacco exhibited with the painting of ship, the smell of furniture cleaning brand Pledge exhibited with the painting of modern home. The role of smell was to represent the visual content in the paintings. Nevertheless, they approached Richard Hamilton's Interior /I 1964 in another way by using the smell of glue to imply the collage process. The role of smell here was to represent the making of the artwork.

Likewise, at Van Abbemuseum in the Netherlands, Anne Nieuwhof's Inhaling Art used smell to reinterpret the visual art in the museum tour. The visitors were invited to sniff the scents related to the artworks by opening the container next to them ("Inhaling Art," n.d.). At the Metropolitan Museum of Art in New York, artist Ezgi Ucar applied the incense, the spices and the powdered fragrances directly on the painting instead of using a smell delivery device. She used the smell of flowers and salt water to enhance the realism of Claude Monet's Garden at Sainte-Adresse (Ucar, 2015). At Kunstmuseum Thun (2017) in Switzerland, there was a series of olfactory exhibitions to explore the role of scents in the collection of the museum. They used the smells to represent the processes of art making and the 
content of art. They also worked with perfumer and artist to create scents inspired by artwork and to make an artwork employing scents. Art museums are often considered to be visually dominant. The attempts above broke the "olfaction silence" in the conventional art experience (El-Khoury, 1996).

\subsection{SMELL AS EXHIBITION EXPERIENCE}

In exhibitions, smell is treated as the display medium for visitors to experience cultural history, to recall social memories, and to understand the change of urban development. Exhibition designer Laura Miotto (2016) used the smell of street food to exhibit the social history of post-war at the National Museum of Singapore. It evoked the visitors the gustatory memories in post-war Singapore. She also used the smell of plants and medicine to represent the indigenous culture. The smells not only evoked the memories of elder visitors, but also let the young visitors experience social memories of the past. Later in an exhibition about Singapore's environmental changes, Miotto used both unpleasant smell (rotting) and pleasant smell (floral) to represent the urban development from a dirty river to a garden city. This contrasting olfactory experience sparked conversation among visitors during the exhibition.

Smell is also treated as a storytelling medium in exhibition. Frederik Duerinck and Marcel Brakel let visitors experience the last moments of John F. Kennedy's death by using scent along with sound in an installation called Famous Deaths. They used narrative scent such as leather, perfume, gunpowder and blood to recreate the scenarios. The visitor had to lay down inside the mortuary cooler in the installation to experience the scenarios (Twilley, 2015). Jorge Otero-Pailos, a professor from Columbia University, collaborated with the curator of Morgan Library \& Museum in Manhattan to convey building history into olfactory experience. He let the visitors hold a sampling device to experience the smell of the old books, ancient furniture and carpets in Morgan library that was built in 1906. He pointed out the important value of smell in the historical and cultural preservation (Kennedy, 2017). Bembibre and Strlič (2017) also proposed to consider smell as intangible heritage with its historic value. They made an odour wheel of historic books as the documentation tool about the historic smells. It was based on the extract information of the volatile organic compounds emitted by the historic books in
St. Paul's Cathedral library in London. They argued that smell was not only a tool to communicate with the visitors, but also an art form to show the identity of the history. The studies above showed that smell has a rich background in art practices. Smells are treated as symbolic of individuals, the imagery of space, and the passing of time. Could it be possible to bring this aesthetic value of smell to the digital age through olfactory technology?

\section{4 | THE USAGE OF DIGITAL OLFACTION}

To provide olfactory experience in the digital context, researchers have been studying how to detect and generate scents through computer system. Japanese scholar Takamichi Nakamoto (2008) proposed the concept of Teleolfaction. It was a system that captured odours through an odour sensing system at a remote site, then transferred the olfactory information through the Internet, finally reproducing the odours via olfactory display in real time to synchronize with the visual information of the remote site. Compared with odour sensing, the studies of olfactory display are gaining more attention in the Human Computer Interaction $(\mathrm{HCl})$ community.

\subsection{AUGMENTED ASPECT}

Olfactory display is often used for the augmenting of visual and audio channels. For example, the scent of chocolate was emitted when the scene of a chocolate factory was shown on the screen (Lwin \& Morrin, 2012). What we smell is what we see. The concept of "Smell-O-Vision" was originated from Sensorama, known as the first virtual reality machine introduced by Morton L. Heilig in 1962 ("Inventor in the Field," n.d.). Due to the technical and fundamental issues caused by the characteristics of odour, a synchronization problem of Smell-O-Vision existed when the scent related to the previous scene remained in the air. Though the concept of Smell-O-Vision hardly gained great success in its era, it has strongly influenced the development of olfactory display in digital media. Smelling Screen is one of the cases. It was an olfactory display system that generated odour distribution on a two-dimensional display screen. It included four fans installed at the four corners of the screen. It emitted the odour into the airflow, and then directed the scented air toward a certain location of the screen. They proposed this system to be used for the odour presentation of virtual objects on 
screen-based applications such as digital signage (Matsukura, Yoneda, \& Ishida, 2013).

\subsection{INFORMATIVE ASPECT}

Olfactory display is also used for information notification. Joseph J. Kaye (2004), a pioneer in digital olfaction, brought to our attention the informative usage of smell based on his research in MIT Media Lab in 2001. He focused on using computer-controlled scent output to convey information and called it Symbolic Olfactory Display. He developed a device called Dollars Scents which was installed at the entrance to display the up-anddown status of the stock market with the scent of mint and lemon. Kaye suggested that olfactory medium could be used for displaying slow moving continuous information. Wijnsma and Tan approached in a similar way by developing a project called Smell of Data that connected the scent dispenser with a computer through Wi-Fi. The dispenser emitted the smell to the user as a warning signal if the computer visited unsecured networks (Wijnsma \& Tan, n.d.). Seah et al. (2014) introduced SensaBubble by using scented bubbles as the carrier to deliver the information. It let the users associate the scent with a person or an event by themselves. The system projected the visual information on the scented bubble. When the bubble was burst, the scent was released as the notification of event. However, the result showed that their users mixed up their associations during the time, not to mention the difficulty that happened while the users tried to identify the difference between the odours, such as the scent of apple and the scent of cinnamon.

\subsection{STIMULATING ASPECT}

Rather than considering smell in its augmented and informative role, Narumi et al. approached from another perspective by using smell to stimulate gustatory perception. They developed a system called Meta Cookie. By detecting the marker pattern printed on the plain flavoured cookie, the system emitted different aromas to the users with the corresponding visual image overlaid on it. Over $70 \%$ of their participants perceived the cookie as having different flavours while the ingredients of the cookie stayed the same. Narumi et al. (2010) treated smell as the substantive medium along with visual stimuli to augment the gustatory perception of users. Later they applied the olfactory display system in a pseudo-gustatory drink by using one olfactory stimulus to simulate two to four similar flavours. They used the scent of mandarin to simulate the flavour of lemon, grapefruit and orange respectively. By using the ambiguity of olfaction and the illumination of visual, they successfully reduced the number of odour sources to represent different olfactory patterns in a pseudo-gustatory simulation system (Narumi, Miyaura, Tanikawa, \& Hirose, 2014). Ranasinghe et al. (2017) followed this approach to develop an interactive drinking utensil called Vocktail. It used smell and colour to stimulate flavour perception. The system came with a mobile application which enabled users to create their customised virtual flavours including salty, sweet, bitter, sour, and umami.

\subsection{ENTERTAINMENT ASPECT}

Smell is considered as a medium for entertainment. Mochizuki et al. (2004) developed Fragra virtual reality game with scents. When the player picked up the virtual apple, the scent of apple was emitted through the head-mounted display . Nakamoto et al. (2008) developed a cooking game by using an odour blending device. The players smelled the scent of the ingredient when doing the virtual cooking. Scentee is one of the companies that try to realize digital olfaction in entertainment. They launched an app called Hana Yakiniku, which meant tasting the barbecue with the nose. It provided the replaceable tanks with three types of scents including short ribs, beef tongue, and buttered potato. Their advertisement claimed that their users could experience the smell of barbecue even though they were simply eating plain rice (Harris, 2013). In 2017, Olofsson et al. suggested that olfactory games could be applied in brain training for health, nutrition and well-being.

\subsection{AMBIENT ASPECT}

Sensory marketing researcher Aradhna Krishna (2012) found that the ambient scent associated with the product increased recall of the brands and emotional connections. As odour-evoked memories last longer than other modalities, the ambient scent brought a longer branding impact on the customers. Moreover, pleasant scents enhanced the customer's evaluation of the products. Carulli et al. (2016) brought the value of ambient scent to industrial product design. They took olfactory display into virtual prototyping to elicit vivid sensory experience 
during the phase of product ideation. They developed a wearable olfactory display to emit different odours with the virtual models of washing machines. It enabled users to interact and experience the new product with the sense of smell while it was still at the stage of prototyping. The result showed that the pleasant odour indeed affected users' evaluation on the shape of a product and the perceived value. Based on the users' emotional response in virtual prototyping, the industrial designers could assess users' attitudes toward the products before the production phase. It greatly helped to reduce the development cost and to shorten the development time of a new product. Later they applied olfactory display with ambient scent for increasing drivers' attention level (Bordegoni, Carulli, \& Shi, 2017), and enhancing readers' immersive learning experience (Bordegoni, Carulli, Shi, \& Ruscio, 2017).

Obrist et al. stated that olfactory experience is considered as one of the future, yet largely being underdeveloped in the area of multisensory experience design in $\mathrm{HCl}$. They proposed that the studies should not only focus on technology-driven issues, but also experience design of smell (Obrist, Tuch, \& Hornbaek, 2014). Later they further urged that the discussion of digital olfaction should expand the focus from problem solving to meaning exploration (Obrist et al., 2016).

\section{5 | THE ART OF DIGITAL SCENT}

Olfactory art has a rich background in exploring the aesthetic value of scents and the meaning behind. As olfactory technology has been advancing in recent years, it opens the possibilities of taking olfactory experience into digital art. Hanahana was one of the early attempts that integrated smell with an interactive art installation. It took smell as the substantive input for interaction whereas the visual channel was treated as the supplement output of smell. When the users put a piece of scented paper on top of a vase, the system would project a virtual flower as a real-time visualization of the scent. According to the intensity and the type of the scent chosen by the users, the colour and the shape of the virtual flower on the projection would be changed correspondingly. This artwork showed the aesthetic expression of digital scent in an interactive way. It also brought the appreciation experience of scent and art together (Kakehi, Chikamori, \& Kunoh, 2007).

Osmodrama was another piece of digital olfactory installation artwork. It was awarded at the fourth annual Art and Olfaction Awards in 2017. The system combined scents with sound to create mental images for the audience in live performance. The team developed a digital scent organ called Smeller 2.0, which included 64 channels for odour emission. They controlled the emission in sequence along with the sound composition. The scent of plants, fruit and food were presented with the sound of birds, rain and planes for example. The audiences were brought into a sensory journey from rain forest to airport through the mental images created by scents and sounds. Scent was treated as the instrument of compositions in the performance. They called it the art of time-based olfactory storytelling ("Osmodrama is the art," n.d.).

TeamLab, a Tokyo-based company well known for its integration of digital art with interactive installations, collaborated with L'Occitane in a project called Digital Provence in 2016. They created the atmosphere of Provence by providing olfactory experience in an interactive installation. When the visitor walked close to a mirror wall, the system released the aroma of flower and projected the virtual flowers around the visitor on the mirror. It brought the beauty of Provence to the visitors through the combination of smell and digital art ("Digital Provence," 2016). The examples above demonstrated how scents were treated aesthetically as the interface to connect the visitors and the artwork. They showed the possibilities of combining digital art with olfactory display.

\section{6 | DISCUSSION}

Current digital olfactory artworks are limited to the expressions of visualization, performance, and exhibition. However, the history of olfactory art shows us that smell can be treated as art in itself, and also as an aesthetic medium to represent people, space and time in a symbolic way. Most current digital olfaction research is technology driven. They focus on how the systems deliver the scents and how people perceive the olfactory experience through computer systems. The aesthetic aspect of digital olfaction has not been widely discussed. This seems to be an area where 


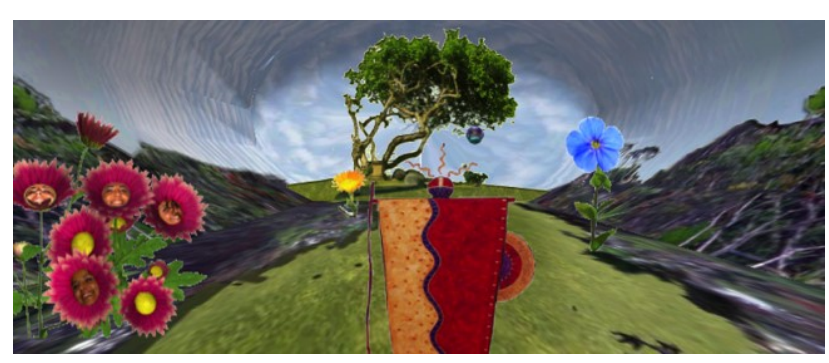

Figure 1 | Digital scents represented the character in gameplay.

people from digital art and digital olfaction can work together to reach great potential.

\subsection{PEOPLE - IDENTITY, IMAGINATION, THERAPY}

Digital scents could bring the symbolic meaning of identities and characters into artwork. Current symbolic olfactory display studies are mainly applied in the usage of information and events. However, studies showed that it might be less effective than other modalities (Bodnar, Corbett, \& Nekrasovski, 2004) and leads to the confusion of associations (Seah et al., 2014). Boyd-Davis et al. (2007) used digital scents to represent the character in gameplay as in Figure 1. The players had to identify the character's wife by remembering her fragrance correctly. The close fit between the story scenario and the use of scent successfully arose the user's engagement. The symbolic usage could be extended from gameplay to art practices. Digital artists could make use of olfactory display to express the identities in the artwork.

By taking artistic expression with digital scents, it could help to evoke the imagination and the mental image in a person's mind. Many digital olfaction applications follow the approach of "Smell-O-Vision" by providing scent to augment the visual-audio channel. We smell what we see. It provides the sense of presence and increases the realism of virtual environment. However, olfaction is subjective experience. By mapping the scent to a certain object, it faces the challenge of individual expectation gap, perceived synchronization (Murray, Qiao, Lee, \& Muntean, 2014) and olfactory adaptation (Ramic-Brkic \& Chalmers, 2014). However, by turning "Smell-O-Vision" to "Vision-OSmell", digital olfactory artwork could provide aesthetic scenarios for the users to create their visual imagery based on the interaction. We see what we smell. $\mathrm{HCl}$ researchers $\mathrm{Cao}$ and Okude (2015) used scents to create sensorial imagination to engage users' minds as in Figure 2. Huang (2014) used mind control to create a series of artistic

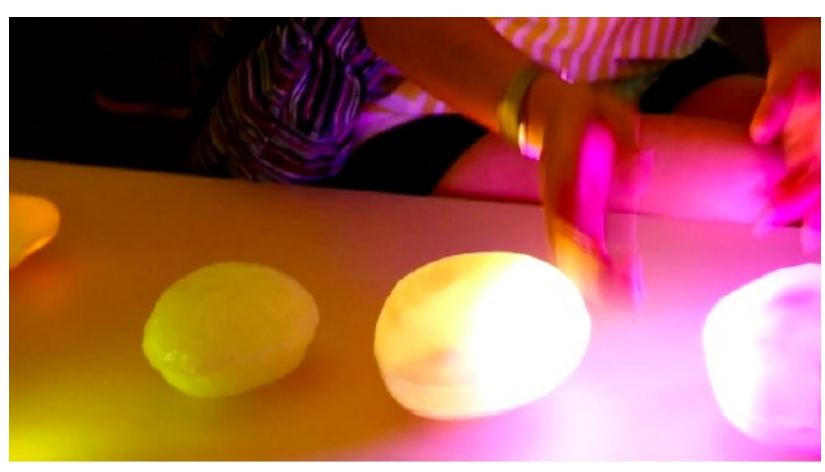

Figure 2 | Digital scents integrated with lighting to evoke sensorial imagination.

connotations with odour and wind effect. Digital olfactory artwork could take it further to provoke people's visual imagery in an aesthetic way.

Digital olfaction could bring the affective impact of smell into art therapy as well. Olfactory researcher Andreas Keller (2014) pointed out that smell sometimes is more effective when it is not consciously perceived. Ischer et al. (2014) proposed that olfactory display could be a powerful tool for clinical virtual therapies, for example, in restoring the memory of brain injury patients, reducing the anxiety of burn victims, and enhancing the behavioural treatments of people with eating disorders. $\mathrm{HCl}$ researchers Amores and Maes (2017) brought the unconscious effects of smell in designing a wearable olfactory display with aromatherapy essential oil. It aimed to affect user's mood and cognitive performance based on biometric data. Digital artists could take it further to combine olfactory technology with art therapy to enhance people's physical, mental, and emotional well-being. Ambient scent could be deployed in an art venue to affect the behaviour of visitors and their perception of the artworks as well.

\subsection{SPACE - LOCATION, NAVIGATION, TERRITORY}

Digital artists could make use of olfactory technology to create digital smellscape as artwork. Artist Kate McLean (2017) visualized the scents and their locations as a map through the smellwalks in different European cities. She claimed the smellmap as an art form which revealed expectations and personal associations of the locations from the participants. It showed the human perception of the urban smellscape. However, the dimension of the smellscape was flat and static. Digital olfactory artists could create an interactive urban smellscape to show the olfactory association among the habitants in the community. 


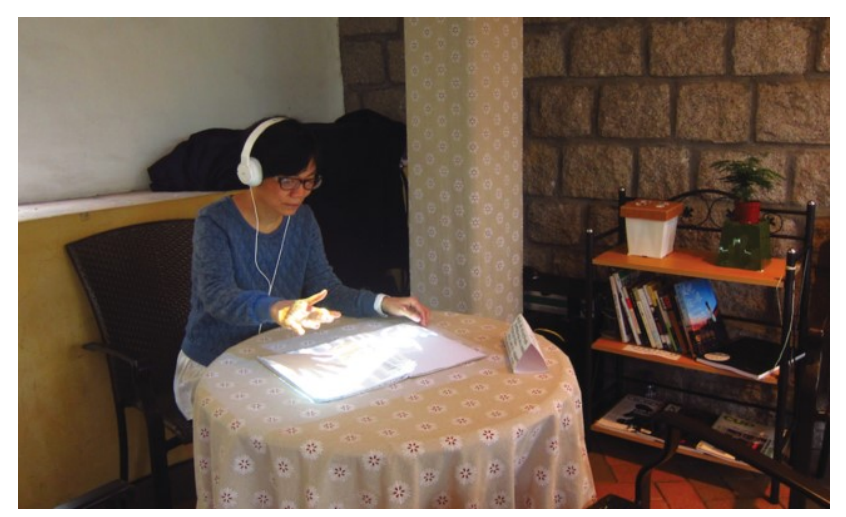

Figure 3 | Digital olfactory artwork provided intangible experience in the heritage site.

Digital olfaction could also provide a sense of navigation in the environment for artwork. Köster et al. (2014) indicated that the role of smell in daily life is to link the people to the affective appreciation of surrounding. Multi-sensory storytelling production company The Feelies provided a sequence of scents with 360 VR film for giving the participants the experience of transporting from New York to Jordan virtually. The scents represented the salty air of a city and the baking bread in a refugee camp for instance (Obrist, Boyle, van Brakel, \& Duerinck, 2017). Maruno et al. (2016) also developed a virtual cocktail maze by using a wearable olfactory display. The user experienced different scents of fruits when getting to the cocktail bar in the maze. Yet these studies were limited on the conventional "Smell-OVision" with virtual navigation. Digital artists could create different routes of scented journeys along with the artworks. It provides an alternative way for people to navigate and appreciate the surrounding in the physical world.

Smell is an intangible media that can provide a new experience in space. Digital artists could use olfactory display to provide intangible experience to the participants in a limited art venue. Lai integrated digital scents in her interactive artwork that was installed in a public library located in a cultural heritage. Her research showed that the digital olfactory artwork prompted interaction between the visitors in the heritage site as in Figure 3 (Lai, 2016). Cultural heritages usually have certain restraints on construction due to the historic and architectural values. By providing interactive olfactory experience in space, it could enrich visiting experience without changing its infrastructure. The olfactory component of the interaction could be changed according to the themes of the exhibitions. Digital olfaction could redefine the territory of the art space.

\subsection{TIME - YESTERDAY, TODAY, TOMORROW}

Digital scents can be treated as a medium for storytelling to express timelines different from traditional art. Social anthropologist Uri Almagor (1990) indicated that smell makes the past exist in the present. Smell connects "then-and-now" together. Digital olfactory artworks can let people experience time travel by emitting scents in different sequences with the artworks. The scents could show the passing of time like morning to evening, and spring to winter. It could also show the passing of life. It recalls in people the memories of the past, enhances the sense of the presence, and stimulates the imagination of the future.

Olfactory cues with digital artworks could help to deliver customized experiences to the visitors over an extended period. Kim et al. once brought the evocative impact of smell into tourism industry. Their study showed that the visitors had significant improvement in recalling the cultural event when they were exposed to the smell of sesame oil encountered in the event (Kim \& Jang, 2016). This could be applied in art festival as well. By providing the signature scent of the art event, it might help the participants associate their visiting experience with the artwork.

\section{7 | CONCLUSION}

Scent has a long history of being treated as a medium of art. Its aesthetic, affective and evocative aspects enrich the art experience. This paper has reviewed how the aesthetic aspect of scents is expressed in the art practices. Previous studies showed that smell could express the symbolic meaning of people, the imagery of the space, and the passing of time. Current digital olfaction researches focus on how users perceive olfactory experience and their task performance through olfactory technology. The studies of aesthetic experience and artistic expression in digital olfaction are worth exploring further. This paper therefore proposed an area where people from digital art and digital olfaction can contribute together to bring out the beauty of scents in the digital age. This paper discussed opportunities based on the framework of people, space and time. Rather than making scented digital artworks, digital olfactory artworks could provide an artistic way for people to appreciate the surroundings through this aesthetic, affective and evocative medium. 


\section{REFERENCES}

Almagor, U. (1990). Odors and private language: Observations on the phenomenology of scent. Human Studies, 13(3), https://doi.org/10.1007/BF00142757

Amores, J., \& Maes, P. (2017). Essence: Olfactory interfaces for unconscious influence of mood and cognitive performance. In Proceedings of the 2017 $\mathrm{CHI}$ conference on human factors in computing systems (pp.

https://doi.org/10.1145/3025453.3026004

Bedini, S. A. (1994). The trail of time: time measurement with incense in East Asia. Cambridge University Press.

Bembibre, C., \& Strlič, M. (2017). Smell of heritage: a framework for the identification, analysis and archival of historic odours. Heritage Science, 5(1), 2. https://doi.org/10.1186/s40494-016-0114-1

Belle Haleine - The scent of art. (2015). Retrieved from

https://www.tinguely.ch/en/ausstellungen/ausstellun gen/2015/Belle-Haleine.html

Bodnar, A., Corbett, R., \& Nekrasovski, D. (2004). Aroma: ambient awareness through olfaction in a messaging application. In Proceedings of the 6th international conference on multimodal interfaces (pp.

https://doi.org/10.1145/1027933.1027965

Bordegoni, M., Carulli, M., \& Shi, Y. (2017). Demonstrating the effectiveness of olfactory stimuli on drivers' attention. In International conference on research into design (pp. 513-523). https://doi.org/10.1007/978-981-10-3518-0_45

Bordegoni, M., Carulli, M., Shi, Y., \& Ruscio, D. (2017). Investigating the effects of odour integration in reading and learning experiences. INTERACTION DESIGN AND ARCHITECTURES(32), 104-125.

Boyd-Davis, S., Davies, G., Haddad, R., \& Lai, M. K. (2007). Smell me: Engaging with an interactive olfactory game. In People and computers XXEngage (pp. 25-40). Springer. https://doi.org/10.1007/978-1-84628-664-3_3

Brooks, K. (2015, May 13). Artist 'Scent Engineers' Plants To Smell Like Dead Bodies, Sperm And Air Pollution. TheHuffingtonPost.com. Retrieved from https://www.huffingtonpost.com/2015/05/13/peter-

de-cupere-scent_n_7274034.html

Buck, L., \& Axel, R. (1991). A novel multigene family may encode odorant receptors: a molecular basis for odor recognition. Cell, 65(1), 175-187. https://doi.org/10.1016/0092-8674(91)90418-X

Cao, Y. Y., \& Okude, N. (2015). Scented pebbles: interactive ambient experience with smell and lighting. In Proceedings of the ninth international conference on tangible, embedded, and embodied interaction (pp. 409-410). https://doi.org/10.1145/2677199.2690873

Carulli, M., Bordegoni, M., \& Cugini, U. (2016). Integrating scents simulation in virtual reality multisensory environment for industrial products evaluation. Computer-Aided Design and Applications, 13(3), 320-328. https://doi.org/10.1080/16864360.2015.1114390

Cities, firms clean up with wins at Japan's first toilet awards. (2015, September 5). The Japan Times. Retrieved from https://www.japantimes.co.jp/news/2015/09/05/natio $\mathrm{nal} / \mathrm{cities}$-firms-clean-wins-japans-first-toilet-awards/

Classen, C., Howes, D., \& Synnott, A. (1994). Aroma: The cultural history of smell. Taylor \& Francis.

Coelho, P. (2002). The Alchemist (English version translated by Alan R. Clark). New York: HarperCollins Publishers Inc.

Corbin, A. (1986). The foul and the fragrant: odor and the French social imagination. Harvard University Press.

Damien Hirst. (1990). A Thousand Years. Damien Hirst and Science Ltd. Retrieved from http://www.damienhirst.com/a-thousand-years

Denizci Guillet, B., Kozak, M., \& Kucukusta, D. (2017). It's in the air: Aroma marketing and affective response in the hotel world. International Journal of Hospitality \& Tourism Administration, 1-14. https://doi.org/10.1080/15256480.2017.1359727

Digital Provence by teamLab, Tokyo | teamLab. (2016, September 16). Retrieved from https://www.teamlab.art/e/loccitane-shinjuku/ 
Doucé, L., Poels, K., Janssens, W., \& De Backer, C. (2013). Smelling the books: The effect of chocolate scent on purchase- related behavior in a bookstore. Journal of Environmental Psychology, 36, 65-69. https://doi.org/10.1016/j.jenvp.2013.07.006

Drobnick, J. (1998). Reveries, assaults and evaporating presences: olfactory dimensions in contemporary art. Parachute, New York: Vintage, 89, 10-19.

El-Khoury, R. (1996). Polish and Deodorize: Paving the City in Late-Eighteenth-Century France. Assemblage (31), 7-15. https://doi.org/10.2307/3171439

Engen, T. (1991). Odor sensation and memory. Greenwood Publishing Group.

Finbow, A. (2015, November). Larry Miller and Tom Russotti, Flux-Olympiad 2008. Retrieved from http://www.tate.org.uk/research/publications/perform ance-at-tate/case-studies/larry-miller-tom-russotti

Gatten, A. (1977). A Wisp of Smoke. Scent and Character in the Tale of Genji. Monumenta Nipponica, 35-48. https://doi.org/10.2307/2384070

Harris, J. (2013, October 31). Scentee makes your phone smell like a cinnamon roll or Korean BBQ when you get a text. Los Angeles Times. Retrieved from http://www.latimes.com/food/dailydish/la-ddsmartphone-smell-bacon-scentee-20131030story.html

Henshaw, V., Medway, D., Warnaby, G., \& Perkins, C. (2016). Marketing the 'city of smells'. Marketing Theory, 16(2), 153-170. https://doi.org/10.1177\%2F1470593115619970

Herz, R. S. (2012). Odor memory and the special role of associative learning. Olfactory Cognition: From Perception and Memory to Environmental Odours and Neuroscience, 85, 95.

Hirsch, A. R. (2006). Nostalgia, the odors of childhood and society. The smell culture reader, 187-189.

Huang, Y. (2014). Interaction, suggestion and artistic connotation: experiment with mind, emotion, odor and wind. In SIGGRAPH ASIA 2014 posters (p. 18). https://doi.org/10.1145/2668975.2669001
Inhaling Art. (n.d.). Van Abbe Museum. Retrieved from

https://vanabbemuseum.nl/en/programme/programm e/inhaling-art/

Inventor in the Field of Virtual Reality Sensorama Machine (n.d.). Retrieved from http://www.mortonheilig.com/InventorVR.html

Installation on the nose. (2008, November 4). Retrieved from http://www.smh.com.au/news/entertainment/arts/inst allation-on-the-

nose/2008/11/04/1225560788267.html

The Institute for Art and Olfaction - Perfume Education and Experimentation. (n.d.). Retrieved from http://artandolfaction.com/

Ischer, M., Baron, N., Mermoud, C., Cayeux, I., Porcherot, C., Sander, D., \& Delplanque, S. (2014). How incorporation of scents could enhance immersive virtual experiences. Frontiers in psychology, $\quad 5, \quad 736$. https://doi.org/10.3389/fpsyg.2014.00736

Kakehi, Y., Chikamori, M., \& Kunoh, K. (2007). hanahana: An interactive image system using odor sensors. In ACM SIGGRAPH 2007 posters (p. 41). https://doi.org/10.1145/1280720.1280766

Kaye, J. J. (2004). Making Scents: aromatic output for $\mathrm{HCl}$ interactions, 11(1), 48-61. https://doi.org/10.1145/962342.964333

Keller, A. (2014). The Scented Museum. The multisensory museum: Cross-disciplinary perspectives on touch, sound, smell, memory, and space, Rowman \& Littlefield. 167-176.

Kennedy, R. (2017, March 3). What's That Smell? Rare Books and Artifacts From a 1906 Library. The New York Times. Retrieved from https://www.nytimes.com/2017/03/03/arts/morganlibrary-book-smell.html

Kim, J. H., \& Jang, S. (2016). Memory retrieval of cultural event experiences: Examining internal and external influences. Journal of Travel Research, $55(3)$, 322-339. https://doi.org/10.1177\%2F0047287514553058

Köster, E. P., Møller, P., \& Mojet, J. (2014). A "Misfit" Theory of Spontaneous Conscious Odor Perception (MITSCOP): reflections on the role and 
function of odor memory in everyday life. Frontiers in psychology, 5 ,

64. https://doi.org/10.3389/fpsyg.2014.00064

Krishna, A. (2012). An integrative review of sensory marketing: Engaging the senses to affect perception, judgment and behavior. Journal of Consumer Psychology, 22(3), 332-351. https://doi.org/10.1016/j.jcps.2011.08.003

Kunstmuseum. (2017). Olfactory Exhibition \#4. How does evil smell? Retrieved from http://www.kunstmuseumthun.ch/en/ausstellungen/v orschau/olfactory-exhibition-3-4-2383/

Lai, M. K. (2016). Flip the Book - Flip the Memories: A Case Study of Multimodal Interaction for the Library Located in Macao World Heritage Site. In Proceedings of the 22nd International Symposium on Electronic Art ISEA 2016 Hong Kong (pp. 297300).

Larsson, M., Willander, J., Karlsson, K., \& Arshamian, A. (2014). Olfactory LOVER: behavioral and neural correlates of autobiographical odor memory. Frontiers in psychology, 5, 312. https://doi.org/10.3389/fpsyg.2014.00312

Lewis, D. (2013). The Brain Sell: When Science Meets Shopping; How the new mind sciences and the persuasion industry are reading our thoughts, influencing our emotions, and stimulating us to shop. Nicholas Brealey Publishing.

Lwin, M. O., \& Morrin, M. (2012). Scenting movie theatre commercials: The impact of scent and pictures on brand evaluations and ad recall. Journal of Consumer Behaviour, 11(3), 264-272. https://doi.org/10.1002/cb.1368

Maruno, T., Iseki, M., \& Nakamoto, T. (2016). Cocktail maze using wearable olfactory display. 3rd World Congress of Digital Olfaction Society.

Matsukura, H., Yoneda, T., \& Ishida, H. (2013). Smelling screen: development and evaluation of an olfactory display system for presenting a virtual odor source. IEEE transactions on visualization and computer graphics, 19(4), 606-615. https://doi.org/10.1109/TVCG.2013.40

McBurney, D. H., Streeter, S., \& Euler, H. (2012). Olfactory comfort in close relationships: You aren't the only one who does it. Olfactory cognition: From perception and memory to environmental odours and neuroscience, 59-72.

McLean, K. (2017). Smellmap: AmsterdamOlfactory Art and Smell Visualization. Leonardo, 50(1), 92-93.

https://doi.org/10.1162/LEON_a_01225

Miotto, L. (2016). Using scents to connect to intangible heritage: Engaging the visitor olfactory dimension: Three museum exhibition case studies. In Virtual System \& Multimedia (VSMM), 2016 22nd International Conference on (pp. 1-5). https://doi.org/10.1109/VSMM.2016.7863208

Mochizuki, A., Amada, T., Sawa, S., Takeda, T., Motoyashiki, S., Kohyama, K., . . . Chihara, K. (2004). Fragra: a visual-olfactory VR game. In ACM SIGGRAPH 2004 Sketches (p. 123). https://doi.org/10.1145/1186223.1186377

Morita, K. (2006). The book of incense: Enjoying the traditional art of Japanese scents. Kodansha International.

Murray, N., Qiao, Y., Lee, B., \& Muntean, G. M. (2014). User-profile-based perceived olfactory and visual media synchronization. ACM Transactions on Multimedia Computing, Communications, and $\begin{array}{lll}\text { Applications } & \text { (TOMM), } & 11 \text { (1s), }\end{array}$ https://doi.org/10.1145/2540994

Nakamoto, T. (2008). Experiment on teleolfaction using odor sensing system and olfactory display synchronous with visual information. Proc. ICAT, Dec. 2008, 85-92.

Nakamoto, T., Otaguro, S., Kinoshita, M., Nagahama, M., Ohin- ishi, K., \& Ishida, T. (2008). Cooking up an interactive olfactory game display. IEEE Computer Graphics and Applications, 28(1). https://doi.org/10.1109/MCG.2008.3

Narumi, T., Kajinami, T., Tanikawa, T., \& Hirose, M. (2010). Meta cookie. In ACM SIGGRAPH 2010 Posters (p. 143). ACM. https://doi.org/10.1145/1836845.1836998

Narumi, T., Miyaura, M., Tanikawa, T., \& Hirose, M. (2014). Simplification of olfactory stimuli in pseudogustatory displays. IEEE transactions on visualization and computer graphics, 20(4), 504512. https://doi.org/10.1109/TVCG.2014.37 
Obrist, M., Boyle, G., van Brakel, M., \& Duerinck, F. (2017). Multisensory Experiences \& Spaces. In Proceedings of the 2017 ACM International Conference on Interactive Surfaces and Spaces (pp. 469-472).

ACM.

https://doi.org/10.1145/3132272.3135086

Obrist, M., Tuch, A. N., \& Hornbaek, K. (2014). Opportunities for odor: experiences with smell and implications for technology. In Proceedings of the SIGCHI Conference on Human Factors in Computing Systems (pp. 2843-2852). ACM. https://doi.org/10.1145/2556288.2557008

Obrist, M., Velasco, C., Vi, C., Ranasinghe, N., Israr, A., Cheok, A., . . . Gopalakrishnakone, P. (2016). Sensing the future of $\mathrm{HCl}$ : touch, taste, and smell user interfaces. interactions, 23(5), 40-49. https://doi.org/10.1145/2973568

Olofsson, J. K., Niedenthal, S., Ehrndal, M., Zakrzewska, M., Wartel, A., \& Larsson, M. (2017). Beyond smell-o-vision: Possibilities for smell-based digital media. Simulation \& Gaming, 48(4), 455-479. https://doi.org/10.1177\%2F1046878117702184

Orlin, M. (2012, November 30). Scent as Pure Art. TheHuffingtonPost.com. Retrieved from http://www.huffingtonpost.com/mary-orlin/museumof-arts-and-design-perfume_b_2193247.html

Osman, A. (2013). Historical Overview of Olfactory Art in the 20th Century. Academia.edu. Retrieved from

http://www.academia.edu/4608919/Historical_Overvi ew_of_Olfactory_Art_in_the_20th_Century

Osman, A. (2015). The Art of Scent \& The Scent of Art. Perfumer \& Flavorist. Retrieved from http://www.perfumerflavorist.com/fragrance/trends/T he-Art-of-Scent--The-Scent-of-Art--295901721.html

Osmodrama is the art of timebased olfactory storytelling via Smeller 2.0. (n.d.). Retrieved from http://osmodrama.com/

Proust, M. (1982). Remembrance of things past, vol. 1, trans. CK Scott Moncrieff and T. Kilmartin, New York: Vintage.

Ramic-Brkic, B., \& Chalmers, A. (2014). Olfactory adaptation in virtual environments. ACM Transactions on Applied Perception (TAP), 11(2), 6. https://doi.org/10.1145/2617917
Ranasinghe, N., Nguyen, T. N. T., Liangkun, Y., Lin, L.-Y., Tolley, D., \& Do, E. Y. L. (2017). Vocktail: A Virtual Cocktail for Pairing Digital Taste, Smell, and Color Sensations. In Proceedings of the 2017 ACM on Multimedia Conference (pp. 1139-1147). ACM. https://doi.org/10.1145/3123266.3123440

Seah, S. A., Martinez Plasencia, D., Bennett, P. D., Karnik, A., Otrocol, V. S., Knibbe, J., . . . Subramanian, S. (2014). SensaBubble: a chronosensory mid-air display of sight and smell. In Proceedings of the SIGCHI Conference on Human Factors in Computing Systems (pp. 2863-2872). ACM. https://doi.org/10.1145/2556288.2557087

Sensorwake Wake Up Happy With The Smell-Based Alarm Clock. (2015). Retrieved from https://www.kickstarter.com/projects/222459303/sen sorwake-wake-up-happy-with-the-smell-based-alar

Shiner, L. \& Kriskovets, Y. (2007). The Aesthetics of Smelly Art. The Journal of Aesthetics and Art Criticism, 65(3), 273-286.

Spangenberg, E. R., Sprott, D. E., Grohmann, B., \& Tracy, D. L. (2006). Gender-congruent ambient scent influences on approach and avoidance behaviors in a retail store. Journal of Business Research, 59(12), 1281-1287. https://doi.org/10.1016/j.jbusres.2006.08.006

Sugiyama, H., Oshida, A., Thueneman, P., Littell, S., Katayama, A., Kashiwagi, M., . . . Herz, R. S. (2015). Proustian products are preferred: The relationship between odor-evoked memory and product evaluation. Chemosensory perception, 8(1), 1-10. https://doi.org/10.1007/s12078-015-9182-y

Sullivan, R. M., \& Toubas, P. (1998). Clinical usefulness of maternal odor in newborns: soothing and feeding preparatory responses. Neonatology, 74(6), 402-408. https://doi.org/10.1159/000014061

Süskind, P. (2001). Perfume: The story of a murderer. Vintage.

Takako Saito. Spice Chess. c. 1977 | MoMA. (n.d.). Retrieved from

https://www.moma.org/collection/works/131553

Tate. (n.d.). IK Prize 2015: Tate Sensorium | Tate. Retrieved from http://www.tate.org.uk/whats-on/tatebritain/display/ik-prize-2015-tate-sensorium 
Teixeira, M. A., Rodríguez, O., \& Rodrigues, A. E. (2010). Perfumery radar: A predictive tool for perfume family classification. Industrial \& Engineering Chemistry Research, 49(22), 1176411777. https://doi.org/10.1021/ie101161v

Tolaas, S. (2006). The Smell of Fear Installation. Retrieved from

https://www.mediamatic.net/en/page/21095/the-

smell-of-fear

Turin, L. (2007). The secret of scent: adventures in perfume and the science of smell. Harper Collins.

Twilley, N. (2015, April 23). What Did Qaddafi's Death Smell Like? The New Yorker. Retrieved from https://www.newyorker.com/tech/elements/art-andolfaction-awards-what-did-qaddafi-death-smell-like.

Ucar, E. (2015, September 8). Multisensory Met: Touch, Smell, and Hear Art. Retrieved from http://www.metmuseum.org/blogs/digital-

underground/2015/multisensory-met

Vilaplana, A., \& Yamanaka, T. (2014). The Waiting Room: Improving Space Through Smell. In KEER2014. Proceedings of the 5th Kanesi Engineering and Emotion Research; International Conference; Linköping; Sweden; June 11-13 (No. 100, pp. 255-267). Linköping University Electronic Press.

Walter de Maria - The New York Earth Room. (n.d.). Dia Art Foundation. Retrieved from https://www.diaart.org/collection/collection/de-mariawalter-the-new-york-earth-room-1977-1980-135/

Waskul, D. D., Vannini, P., \& Wilson, J. (2009). The aroma of recollection: Olfaction, nostalgia, and the shaping of the sensuous self. The Senses and
Society,

$4(1)$,

$5-22$.

https://doi.org/10.2752/174589309X388546

We stopped just here at the time. (2002). Retrieved from

https://www.centrepompidou.fr/cpv/resource/cbLEa5

$\mathrm{X} / \mathrm{rGb} 9 \mathrm{EKk}$

Wei, K. (2015, April 27). Exploring old Taipei following your nose. The China Post. Retrieved from https://chinapost.nownews.com/20150427-44281

Wijnsma, L., \& Tan, F. (n.d.). Smell of Data. Retrieved from https://smellofdata.com/

\section{BIOGRAPHICAL INFORMATION}

Mei-Kei Lai is a lecturer and Assistant Programme Coordinator of the Design Programme in the School of Arts at Macao Polytechnic Institute. She received her doctoral degree in Media Design from Keio University in Japan, and a postgraduate degree in Design for Interactive Media at Middlesex University in the United Kingdom. With a background in technology and design, her research interests concern olfactory interaction with digital art. Her works focus on exploring the possibilities of using smell as a medium to design playful user experience. The experiments include taking smell into the areas of gameplay, exhibition display and family bonding. Her works have been presented in the exhibitions and the conferences in Europe and Asia, such as $\mathrm{HCl}$, SIGDOC, ISEA, Digital Olfaction Society World Congress and Microwave International New Media Arts Festival. She has also held Scent of Art workshop in Hong Kong and Singapore. 